\title{
Sexual violence in women: a review of the literature from psychology
}

\author{
Fernanda Nogueira Silva'; Mayara Pérola Maciel dos Santos ${ }^{2 *}$; Fabiane Gonçalves ${ }^{3}$
}

1 Graduated in Psychology from the Faculty of Human Sciences of Olinda-FACHO and graduated in Psychology also from FACHO. He has experience in clinical psychology mainly in the care of children, adolescents and adults. Studies and performance with emphasis in the school area in the mediation and inclusion of children with ASD.

2 Graduated in Psychology from the Faculty of Human sciences of Olinda- FACHO; Postgraduate in Interventional Actions in Clinical Psychology at FACHO; Master's student in Education, Cultures and Identities at the Federal Rural University of Pernambuco - UFRPE. He has experience in clinical psychology, in the care of babies, adolescents and adults. He is interested in studies and research, Psychoanalysis and Culture, Educational practices in early childhood, Education and Psychoanalysis.

3 Master in Cognitive Psychology from the Federal University of Pernambuco. She is an Adjunct Professor in the Department of Psychology at the Faculty of Human Sciences of Olinda. He has experience in Psychology, with emphasis on Cognitive and Clinical Psychology, working mainly on the following topics: Language, Body, Gender, Development and Culture

E-mail adresses: fernanda.nogueira94@hotmail.com (Fernanda Nogueira Silva), mayaraperolam@gmail.com (Mayara Pérola Maciel dos Santos), fabianemsg@facho.br (Fabiane Mônica Gonçalves),

${ }^{*}$ Corresponding author

\section{To cite this article:}

Silva, F.N.; Santos, M.P.M.; Gonçalves, F.M. Sexual violence in women: a review of the literature from psychology. International Journal of Sciences. Vol. 1, No. 3, 2021, pp. 116-1220. ISSN 2763-5392

Received: 05 14, 2021; Accepted: 05 14, 2021; Published: 05 24, 2021

\begin{abstract}
Patriarchal tradition has long assigned man an "active" role in the social and sexual relationship between the sexes, while decreasing female sexuality to passivity and reproduction. If not, the woman was left the place of procreator and owner of the home, with the advent of feminism, the woman began to occupy important spaces, but still with many challenges. Thus, the maintenance of sexist speeches and violence against women, show a social symptom of rejection of women and control of bodies, as in sexual violence. In this sense, the objective of this research was to investigate the academic productions published in the field of psychology, in the databases (BDTD, SciELO and CAPES Periodical) in the period from 2010 to 2020, about sexual violence in women. What has Brazilian psychology produced, from the point of view of theoretical articulation about sexual violence in women and their psychic repercussions? As a result, we had 88 scientific materials that were analyzed, with only 16 of these data, included with regard to the research objective. With this systematic literature review, it was noticed that the area of psychology concentrates little volume of discussion in relation to sexual violence, in this space of a decade, and in relation to theories or approaches used by researchers to understand the phenomenon, the Social psychology has been widely used, while other aspects of psychology are rarely raised. In this way, this research adds up and also arouses the interest of psychologists and academics for the exploration and greater scientific discussions on this theme, since it is so current and pertinent for study.
\end{abstract}

Keywords: Sexual violence. Women. Social symptom

\section{Introduction}

Sexual violence can be understood as a universal phenomenon, in which there is no restriction of sex, age, ethnicity or social class, and even encompassing men and women, is much more incident in women, which allows us to take into account the misogynistic and sexist social constructions that Brazilian culture still reproduces. It's not for the that many young women and adolescents find themselves in the statistics at higher risk of suffering this type of violence. It can happen in a subtle way, sexual violence against women is not always denounced, for various issues, being one of the main, the trial.

From the historical point of view, sexual violence against women evidences a hierarchy based on gender, a kind of control of the body that violates the intimacy of the same. The control of the feminine, is something that has been reproducing for centuries and it can be said that it is a mechanism that is sophisticated, and seems not to be 
"dangerous or violent".

When talking about sexual violence, there is in the social imaginary the presence of significant rape, which involves a form of dominance over the woman's body, and is often accompanied by physical violence. However, many reports of this type of (sexual) violence occur so intra family, sex without consent and even sexual harassment, as harassment. To the extent that a place of submission for women is still sustained, through patriarchal social discourses, female objectification removes the ability of women to act on the process of violence, and to change its context. Therefore, many cases of sexual violence are not reported.

It enters this discussion, the term rape culture, "process of social embarrassment that guarantees the maintenance of gender roles" (SEMÍRAMIS, 2013). That is, the woman, even if she is sexually assaulted, is guilty of the situation. It is a discourse that ends up legitimizing and normalizing this type of violence, blaming women and objectifying her. "She should wear a more decent outfit, or not go out on the street sometime."

With regard to statistics, the Public Safety Forum (2020) revealed that in 201866,041 cases of sexual violence were reported, of which about $81.8 \%$ are women, $50.9 \%$ black and $48.5 \%$ white. These data reveal that it is necessary to take into account the inter-actions in coping with violence against women. About this, it is worth mentioning that although violence affects all women and social classes, the data show us that black women are the most affected, which leads us to debate about structural racism and stereotypes that mark the body of black women.

Psychology as a science that studies human behavior and the processes of subjectivation has been involved and interested in the articulations between the subjectivity of women and the social markers that reproduce violence. In psychological doing, the demands for care for women victims of violence are very recurrent, for this it is important to discuss and promote questions about the effects of sexual violence, in particular, on the subjectivity of women. Given this scenario, the objective of this research is to investigate the academic productions published in the field of psychology, in the databases (BDTD, SciELO and the CAPES Journal) in the time space from 2010 to 2020, about sexual violence in women. Our interest is to know what is being discussed and produced in the field of Brazilian psychology, about sexual violence in women, with regard to its subjectivity and what theoretical readings are being carried out in the understanding of the phenomenon of this violence.

\section{Methodology}

With regard to the methodology chosen in this work, we chose to perform the method of systematic review of the literature, which consists of an investigative work, a thorough one that seeks knowledge as a foundation basis such for the whole of are search. The elaboration is justified, first, in the academic field by raising to the maximum degree of importance on the proposed theme; as it is also justified by the intention to make it evident in the productions of the last ten years of publications in articles, dissertations or theses in the area. Based on the assumption that Psychology is questioned about collective and social processes, the discussion of genesis in scientific publications contribute to the demystification of stigmas and gender stereotypes, symptomatic in our society.

Thus, they were searched in three Brazilian databases: Thesis and Dissertations Database (BDTD), SciELO (Scientific Electronic Library Online) and the CAPES Journal. The searches were conducted from October/2020 to March 2021, using the descriptors: Sexual violence, woman, rape and Psychology.

The interest of this review was to understand, from the scientific articles, dissertations and theses already published, how Brazilian Psychology has studied sexual violence in women, more specifically which areas of psychology have had more emphasis on addressing the theme, which psychological approaches study and publish more about sexual violence in women. Thus, we chose to delimit the publication period from 2010 to December 2020, and in relation to the language of the materials, Portuguese (Brazil) was selected.

At first, duplicate articles were excluded between the databases consulted. After that, three inclusion criteria were applied: having as its main theme sexual violence in women, it should be related to the area of Brazilian Psychology, and have been published from 2010 to December 2020. To check the first criterion, we analyzed title, abstract and keywords of articles, dissertations and theses. For the second criterion, the psychology approaches that study the theme were analyzed. Based on this analysis, the following were included: (a) all published articles, dissertations and theses available in the databases that we explain here; and (b) materials that are related to sexual violence in women; (c) publications will be considered, belonging to research courses in psychology; (d) from 2010 to the month of 2020 .

\section{Results and Discussions}

Regarding the results of our systematic review, the initial search in the databases (BDTD, SciELO and CAPES Journals) generated a total of 88 scientific materials, including articles, dissertations and doctoral theses. Of this quantitative, 30 dissertations were found in BDTD, 6 articles found in SciELO, and 51 scientific materials are found in the CAPES Journal. Inclusion criteria include the specificity of seeking articles, dissertations and doctoral theses that address the theme of sexual violence in women from 2010 to 2020, with the use of the aforementioned descriptors; Thus, the findings that had in the title, abstract or keywords, aspects related to sexual violence in women, articulated to psychological theories or that discussed the subjectivity of women in the face of this violence, were analyzed.

It is interesting to point out that in the accomplishment of this research, the vast majority of the findings were in other areas of health and human ities, such as collective health, medicine, social work, anthropology, law, nursing. This raises pertinent questions about productions in other areas with regard to sexual violence. 
Thus, the final database included in the analysis of this study considered that only 16 scientific findings of the 88 materials analyzed referring to the three databases fit the research criteria. In the table below we explain, which approaches (theoretical readings of psychology) that researchers used to understand sexual violence in women.

Table 1. List of theoretical approaches found in systematic review

\begin{tabular}{l|c}
\hline \multicolumn{1}{c|}{ Approaches used } & Quantitative work \\
\hline social psychology & 10 \\
\hline Psychological Assessment & 3 \\
\hline Systematic review & 1 \\
\hline Developmental psychology & 1 \\
\hline Legal Psychology & 1 \\
\hline
\end{tabular}

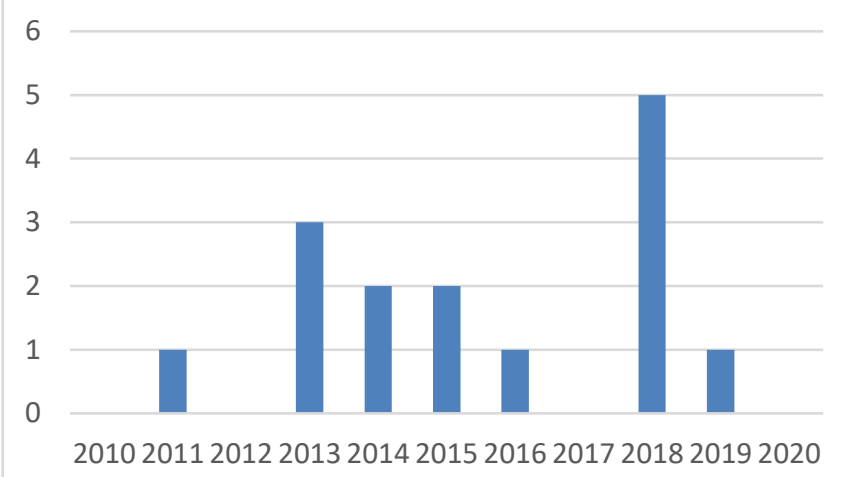

Figure 1. Number of publications on sexual violence per year

Analyzing the 16 scientific publications, the result of our systematic review, it is possible to perceive that the social approach is a theoretical contribution widely used by researchers. In this sense, it is worth pointing out that no humanistic, phenomenological and even psychoanalytic theories were found in the discussion of sexual violence against women. In this sense, we emphasize the importance and need to base studies in the area of psychology, in the discussion of gender.

Thus, there is not only "only" physical and psychological damage, as a social consequence, we fear rape an axis of the condition of being a woman, limiting it in many aspects of your life (DINIZ, 2013). The association of women as a fragile subject invokes justifications for prejudice, and because it is a violence related to gender, it occurs due to behaviors of inequality in relationships based on a hierarchy (BANDEIRA, 2014).

Also, according to the author (2014) sexual violence became a claim from feminist movements in 1970, but only decades later did it gain visibility in the area of sociology research. It is noteworthy that these $r$ elations of violence exist and arise with the theme of gender violence due to unequal relations of power that involve people's lives. And to regulate these relationships with the gender perspective, male violent action serves as the basis of functioning, therefore, in the domestic and family sphere, violence is mostly practiced by men. That in a naturalized way, they appear and invisible to the vast majority, which sustains this relationship of man's authority over women (CHACHAM; JAYME, 2016). The feminist movement has shown what was once veiled, and that despite the resistance around the word, it is a legitimate movement that has been going through society for decades and that is enabling important transformations in the relations between men and women, which in the eyes of Duarte (2019), is a broad movement that should be considered any gesture or action that goes against the oppression and discrimination of women. However, there are now articulated movements for certain flags.

It is not worth in research criticism of the various branches of which the movement has adopted, they even have as characteristic the attempt to understand the diversity of meaning around what it is to be a woman and how it reaches them subjectively. Therefore, there is no tone to understand what is significant or not, since being a woman is not a universal category. Since, according to Pitanguy (2019) one can make an association that there is no linear trajectory for progress and that yes, flags can also become objects of study. When we talk about sexual violence, the focus of study, we also talk about a public health problem that affects all women worldwide. In the Brazilian code in Law No. 12,015 of August 7, 2009, Title VI of crimes against sexual dignity, Chapter I defines crimes against sexual freedom: Rape, which consists of constraining someone through violence to have carnal conjunction or libidinous act, sexual rape by fraud which also consists of carnal conjunction or libidinous act, only, through fraud or preventing the free manifestation of the victim and finally, sexual harassment that has its sentence increased if the victim is under 18 years of age.

In chapters II, V and VII of that same Law we find definitions for sexual crimes against the vulnerable and trafficking of persons for the purpose of prostitution or other form of sexual exploitation and general provisions on. As research delimitation, no form of these explained in the Law was defined as an exclusion criterion.

It can also be seen in the Maria da Penha Law no. 11,340, of August 7, 2006, in Chapter II, when referring to forms of domestic and family violence against women, sexual violence is understood $(\mathrm{s} / \mathrm{w})$ :

\begin{abstract}
As any conduct that constrained it to witness, maintain or participate in unwanted sexual intercourse, through intimidation, threat, coerque or use of force; which induces it to market or use, in any event, its sexuality, to prevent it from using any contraceptive method or to force it into marriage, pregnancy, abortion or prostitution, through coercose, blackmail, bribery or manipulation; or that limits or nullifies the exercise of your sexual and reproductive rights.
\end{abstract}

According to Lima and Deslandes (2014), despite the social and political obstacles related to the theme of gender violence, technical responses and public policies deal with a collective effort and involvement of the most diverse sectors of society that contribute to coping with and inhibiting this type of violence here in Brazil.

Although there is a great obstacle to sexual violence, since it is little denounced, which makes it difficult to present 
statistical records and research in this area run the path of lack of reliability in the data presented, since many women are still ashamed or are not legally and socially protected in a broad and compromised way, leaving many women at that time , alone and without information during the process. Even if it is known, both by the scientific and social community, that this type of violence can lead to bodily injury, an unwanted pregnancy, in addition to impacts on the psychological state of women, which often lead to psychosomatic diseases, anxiety, depression and even lead to suicidal behaviors and ideations (SOUZA; ADESSE, 2005).

Corroborating, Berguer (2003) speaks not only of these invisibilities of violence and the difficulty of records, but of a scarcity of academic production on the subject both in the public and private spheres, also taking as a challenge, to what extent these gender relations prevented or trivialized the visibility of sexual violence. The author also expresses the difficulty of women identifying the limits between consenting sexual desire and when their desire is not taken into consideration, especially when we speak in complex contexts as another of the difficulties.

Another point needed to discuss the studies conducted by Trentin et al. (2019) it is possible to perceive among the issues addressed the need for a team prepared for care, which often, due to the lack of proper management, cannot go beyond the stigma, criminalization and blaming of the victim, thus reflecting the aspects of gender violence. The contribution of this study to the multidisciplinary team is the reflection on what involves the elements in the realization of the effectiveness of care. In this field of psychology, area of study, Silva and Vagostello (2017), highlight the importance of welcoming in care as a facilitator of bond creation, so necessary for psychological care to actually happen. They expose that the intervention process aims to prevent symptoms that may appear due to trauma, elaboration and reintegration of this woman to the social.

In the interviews conducted by this study with psychology professionals, they also reveal the importance of self-care and professional qualification to deal with work wear, because in their reports they explain the lack of specialized services and mental health professionals who know how to deal with the demands of women who have suffered sexual abuse. Simiano and D'Avila (2019) also align with previous authors when they talk about the importance of the therapeutic bond, thus transforming the environment into a safe and welcoming place. Therefore, it is necessary that the professional is aware of his role in the care of this specific audience, providing the sharing of traumatic experience and the aspects affected in his life.

Typing domestic violence in addition to defining it, as well as the laws of support and protection of women victims, and places of insertion of the professional psychologist and its importance in the context of care and support in situations of domestic violence are objectives of this work (SIMIANO; D'AVILA, 2019, p. 3).

It is not possible to deny the extreme importance of the work of the psychology professional, whatever the region or place of care, its performance is based on a technical and scientific equipment, as well as the Laws that govern and support the victims. However, as mentioned, it is possible to identify in the data found in the last 10 years the deficiency of materials that underlie and expand discourses on the theme of sexual violence. The authors Simiano and D'Avila (2019) even highlight the expansion of the role of the psychologist making it more accessible to victims of abuse considering that they do not only affect the victimized subject, but the whole society.

\section{Conclusions}

In view of all the discussion proposed in this article, it is worth mentioning that sexual violence against women can be understood as a social symptom, which is reproduced through discourses. The culture of rape brings this conception that there is a trivialization in violence against women, and that even in the face of an experience of mastery and aggressive, the woman feels embarrassed and guilty for having been raped. That is why sexual violence is still little reported, hindering its statistical record and research in this area, since many women are not legally and socially protected in a broad and compromised way, leaving the woman, often alone and without information during the process.

Understanding the phenomenon of this violence is something important for professionals who work in welcoming and listening to such demands, not only for notification aspects, but so that through speech, the woman can elaborate the pains of having her body violated. For this, it is important to have discussions and research in this focus of work, being able to articulate the knowledge and theory of psychology with regard to intervention and understanding of the effects of violence on the psyche of women.

We then proposed to make a systematic review of the bibliography in three databases (BDTD, SciELO and CAPES), we had 88 scientific materials, to which they were analyzed, only 16 papers fit the inclusion criteria, taking into account the temporal demarcation from 2010 to 2020, and the theme of sexual violence with regard to Brazilian psychology. It was possible to perceive that social psychology is the theory (approach) most used to establish readings and discussions about sexual violence and its repercussions on women's subjectivity. In a decade, we noticed that the amount of academic productions with this theme is still in volume and diverse, with regard to other approaches proposing discussions about. Psychology as a science seeks to question these power structures, which affect subjectivities and reproduce violence, is the part of the psychologist to potentiate social criticism, and scientific publication can be one of the means, important for conveying and sharing such issues. It is expected that from this article, more questions may arise for the deepening of studies on sexual violence against women.

\section{Acknowledgements}

We first thank God, who gives us strength and inspiration in the struggles experienced. We also thank our family and friends for all the support and cheers for our victory. 


\section{References}

[1] BANDEIRA, Lourdes Maria. Violência de gênero: a construção de um campo teórico e de investigação. Revista Sociedade e Estado, Brasília, v. 29, n. 2, 2014. Disponível em: https://www.scielo.br/pdf/se/v29n2/08.pdf. Acesso em: 10 fev. 2021 .

[2] BERGER, Sônia Maria Dantas. Violência sexual contra mulheres: entre a (in)visibilidade e a banalização. Rio de Janeiro, f. 194, 2003. Dissertação - Escola Nacional De Saúde Pública - Fundação Oswaldo Cruz, 2003. Disponível em: https://www.arca.fiocruz.br/bitstream/icict/4909/2/ve_sonia_m aria_ENSP_2003pdf. Acesso em: 10 jan. 2021.

[3] BRASIL. Congresso Nacional. Lei n. 11.340, de 07 de agosto de 2006. Diário Oficial da União. Brasília. Disponível em: http://www.planalto.gov.br/ccivil_03/_ato2004-

2006/2006/lei/111340.htm. Acesso em: 10 fev. 2021.

[4] BRASIL. Congresso Nacional. Lei n. 12.015, de 07 de agosto de 2009. Diário Oficial da União. Brasília. Disponível em: http://www.planalto.gov.br/ccivil_03/_ato2007-

2010/2009/lei/112015.htm. Acesso em: 10 fev. 2021.

[5] CHACHAM, Alessandra Sampaio; JAYME, Juliana Gonzaga. Violência de gênero, desigualdade social e sexualidade: As experiências de mulheres jovens em Belo Horizonte. Civitas, Porto Alegre, v. 16, n. 1, 2016. pp. 1-19. Disponível em: https://www.scielo.br/pdf/civitas/v16n1/1984-7289-civitas-1601-e0001.pdf. Acesso em: 2 fev. 2021.

[6] DINIZ, Débora. Violência sexual. Dossiê violência contra as mulheres. 2013. Disponível em:https://dossies.agenciapatriciagalvao.org.br/violencia/viole ncias/violencia-sexual. Acesso em: 2 fev. 2021.

[7] DUARTE, Constância Lima. Feminismo: uma história a ser contada. In: HOLLANDA, Heloisa Buarque de. Pensamento Feminista Brasileiro: formação e contexto. Bazar do tempo: Rio de Janeiro. 2019. pp. 26-51.

[8] Elisandro Lotin de Souza (Coord.). Anuário Brasileiro de Segurança Pública. Fórum brasileiro de segurança pública, v.13, 2019. Disponível em: https://www.forumseguranca.org.br/wpcontent/uploads/2020/03/Anuario-2019-FINAL_21.10.19.pdf. Acesso em: 9 abr.2021.

[9] GÉLEDES, Instituto da Mulher Negra. Sobre a cultura do estupro, por Cynthia Semíramis. 14 abr. 2013. Disponível em Acesso em: 10 abril. 2021.

[10] LIMA, Claudia Araújo de; DESLANDES, Suely Ferreira. Violência sexual contra mulheres no Brasil: conquistas e desafios do setor saúdem na década de 2000. Saúde Soc. São Paulo, v. 23, n. 3, 2014. pp.787-800. Disponível em: https://www.scielo.br/pdf/sausoc/v23n3/0104-1290-sausoc-

23-3-0787.pdf. Acesso em: 10 fev. 2021.

[11] OLIVEIRA, Hanna Karolline Sousa de; RESENDE, Gisele Silva Lira de. Violência sexual: uma análise social da cultura do estupro. Perspectivas em diálogo: Revista de Educação e Sociedade. Naviraí, v. 7, n. 14, 2020. Disponível em: http://seer.ufms.br/index.php/persdia/. Acesso em: 7 abr. 2021.

[12] PITANGUY, Jacqueline. Carta das mulheres brasileiras aos constituintes: memórias para o futuro.In: HOLLANDA, Heloisa Buarque de. Pensamento Feminista Brasileiro: formação e contexto. Bazar do tempo: Rio de Janeiro. 2019. pp. 90- 108 .
[13] SALDANHA, Marília; NARDI, Henrique Caetano. Uma psicologia feminista brasileira? Sobre destaque, apagamento e posição periférica. Rev. psicol. polít. [online]. 2016, vol.16, n.35, pp. 35-52. Disponível em: http://pepsic.bvsalud.org/scielo.php?sc016000100003. Acesso em: 6 abr. 2021.

[14] SILVA, Erick Pereira da; VAGOSTELLO, Lucilena. Intervenção psicológica em vítimas de estupro na cidade de São Paulo. Arq. bras. psicol. [online]. 2017, vol.69, n.3, pp. 183-198. Disponível em: http://pepsic.bvsalud.org/scielo.php?script=sci_arttext\&pid=S 1809-52672017000300013. Acesso em: 10 mai. 2021.

[15] SIMIANO, Rafaela; D'AVILA, Luciane da Silva. O papel do psicólogo no atendimento a mulheres vítimas de violência doméstica, p. 10, 2018. Disponível em: http://www.uniedu.sed.sc.gov.br/index.php/pos-

graduacao/trabalhos-de-conclusao-de bolsistas/trabalhos-deconclusao-de-bolsistas-a-partir-de-

2018/csaude/especializacao-2/932-o-papel-do-psicologo-noatendimento-a-mulheres-vitimas-de-violencia-domestica/file. Acesso em: 5 jan. 2021.

[16] SOUZA, Cecília de Mello e (Org.); ADESSE, Leila (Org.). Violência Sexual no Brasil: perspectivas e desafios. Ipas Brasil, Brasília, p. 187, 2005 . Disponível em: http://bvsms.saude.gov.br/bvs/publicacoes/violencia_sexual_b rasil.pdf. Acesso em: 9 jan. 2021.

[17] TRENTIN, Daiane et al.. Atendimento a mulheres em situação de violência sexual: revisão integrativa da literatura. Esc. Anna Nery, Rio de Janeiro, v. 23, n. 4, 2019. Disponível em: https://www.scielo.br/scielo.php?pid=S1414$81452019000400701 \&$ script $=$ sci_arttext\&tlng=pt. Acesso em: 10 mai. 2021. 